Original scientific article / Izvirni znanstveni članek

\title{
The Heyman Survey of nursing employees' attitudes towards mechanical restraints in Slovenia
}

\author{
Heymanova lestvica odnosa zaposlenih v zdravstveni negi do posebnih varovalnih \\ ukrepov v Sloveniji
}

Branko Bregar, Brigita Skela-Savič, Karmen Kajdiž, Blanka Kores Plesničar

\section{Key words: nursing; nurses; coercive measures; psychiatry; violence}

Ključne besede: zdravstvena nega; medicinske sestre; prisilni ukrepi; psihiatrija; nasilje

Senior Lecturer Branko Bregar, MSc, RN; University Psychiatric Hospital Ljubljana, Studenec 48, 1260 Ljubljana Polje, Slovenia and Angela Boškin Faculty of Health Care, Spodnji Plavž 3, 4270 Jesenice, Slovenia

Correspondence e-mail / Kontaktni e-naslov: branko.bregar@psih-klinika.si

Associate Professor Brigita Skela-Savič, PhD, MSc, BSc, RN, Research Counsellor; Angela Boškin Faculty of Health Care, Spodnji Plavž 3 , 4270 Jesenice, Slovenia

Karmen Kajdiž, BSc

Professor Blanka Kores Plesničar, PhD, MD, Spec. of Psychiatry

Both /Obe: University Psychiatric Hospital Ljubljana, Studenec 48, 1260 Ljubljana Polje, Slovenia

\begin{abstract}
Introduction: Attitudes of nursing employees towards mechanical restraint are directly connected to their incidence. The purpose of this research was to examine the attitudes of psychiatric nursing staff towards the use and administration of mechanical restraints.

Methods: The cross-sectional descriptive study was conducted using a structured Heyman-type survey. All the Slovenian nursing staff in psychiatric hospitals participated on a given day $(n=367)$.

Results: Differences were observed in the average duration of administered mechanical restraint between individual hospitals $\left(\chi^{2}=43.770, p<0.001\right)$. Staff most often stated that patients felt angry when subjected to mechanical restraint $(n=328,89.4 \%)$. Nonetheless, the majority of respondents believe that mechanical restraints can be an effective therapeutic tool $(n=343,91.6 \%)$. Females $(U=11450.50, p=0.025)$ and with higher education $(U=9527.00, p=0.002)$ experience statistically significantly more negative emotions and are less inclined to use mechanical restraints.

Discussion and conclusion: It is evident that in addition to the factors we researched some other factors are more influential when the incidences of coercive measures are closely studied. Due to some variation between hospitals it would be advisable to review the current clinical practices in this field. The management of health institutions should be considered an essential factor in the efforts to decrease mechanical restraint use.
\end{abstract}

\section{IZVLEČEK}

Uvod: Odnos zaposlenih v zdravstveni negi do posebnih varovalnih ukrepov je povezan z njihovo pojavnostjo. Namen raziskave je bil raziskati odnos zaposlenih $\mathrm{v}$ zdravstveni negi do posebnih varovalnih ukrepov.

Metode: Izvedena je bila presečna raziskava $\mathrm{z}$ uporabo Heymanove lestvice o odnosu do posebnih varovalnih ukrepov med vsemi zaposlenimi v zdravstveni negi $(n=367) \mathrm{v}$ psihiatričnih bolnišnicah v Sloveniji.

Rezultati: Med slovenskimi psihiatričnimi bolnišnicami so ugotovljene razlike $\mathrm{v}$ trajanju posebnih varovalnih ukrepov ( $\left.\chi^{2}=43,770, p<0,001\right)$. Zaposleni se najpogosteje strinjajo, da pacient med posebnim varovalnim ukrepom čuti jezo $(n=328,89,4 \%)$. Kljub temu večina anketirancev verjame, da so posebni varovalni ukrepi lahko učinkovito terapevtsko orodje $(\mathrm{n}=343,91,6 \%)$. Ženske $(U=11450,50, p=0,025)$ in višje izobraženi zaposleni $(U=9527,00, p=0,002)$ izražajo statistično bolj negativna čustva in manj odobravajo posebne varovalne ukrepe.

Diskusija in zaključek: Ob raziskovanju pojavnosti prisilnih ukrepov je jasno, da poleg dejavnikov, raziskovanih v naši študiji, obstajajo tudi drugi, bolj vplivni dejavniki. Zaradi razlik med bolnišnicami bi bilo treba pregledati obstoječo klinično prakso. Predvideva se, da je management zdravstvenih inštitucij pomemben dejavnik pri zmanjšanju pojavnosti posebnih varovalnih ukrepov.
The article is based on the research as part of the doctoral thesis by Branko Bregar $A$ model of factors that explain the psychiatric nursing employees' attitudes to using mechanical restraints.

Received / Prejeto: 3. 5. 2018 Accepted / Sprejeto: 26. 1. 2019 


\section{Introduction}

Coercive measures in psychiatric treatment consist of seclusion (seclusion room), restraint (physical or mechanical restraint), and chemical (pharmacological) restraint. The lawful forms of coercive measure use differ in individual countries, and their practical incidence also frequently varies within the same country (Raboch, et al., 2010; Janssen, et al., 2011). In most cases, coercive measure application is governed by mental health legislation. While various forms of coercive measures are primarily used to ensure the safe treatment of patients who are considered at risk for auto- and hetero-aggression, and for the protection of health care employees, such measures also entail the hazard of unexpected adverse events. Since these events may be as severe as patient death, the use of coercive measures alone already has an indirect effect on stress of conscience, and the general well-being and satisfaction of psychiatric health care patients and staff (Stewart, et al., 2010; Strout, 2010; Gates, et al., 2011; Hollins \& Stubbs, 2011; Berzlanovich, et al., 2012; Van der Merwe, et al., 2013; Whitecross, et al., 2013). The professionals in the health sector and interested publics have, accordingly, been investing considerable efforts into decreasing the incidence of coercive measure use, especially as recent research has revealed that the incidence of such use primarily depends on the nurses' attitude towards applying the measures in the first place (Happell, et al., 2012). The profession is thus experiencing gradual changes in the attitude of psychiatric nursing staff towards the use of coercive measures although these changes are most often the result of organizational measures implemented by individual institutions (Espinosa, et al., 2015). However, change appears to be occurring slowly. The proportion of psychiatric nursing staff condoning the use of coercive measures remains very high (Gelkopf, et al., 2009).

Due to conflicting guidelines and recommendations, medical institutions are experiencing disagreements when it comes to addressing this issue, which consequently impedes the systemic examination of incidence rates and problems related to the use of coercive measures, not only on the international level, but even on the level of individual countries (Bowers, et al., 2004; Knutzen, et al., 2013; Soininen, et al., 2014). Scientific treatment is further hindered by the fact that researchers are employing a wide range of different quantitative and qualitative research methods that are often incompatible from the methodological standpoint (Gelkopf, et al., 2009; Bergk, et al., 2010; 2011; Happell \& Koehn, 2010; Happell, et al., 2012; Van der Merwe, et al., 2013; Steinert, et al., 2013; Ejneborn Looi, et al., 2015).

In spite of the hurdles, certain significant conclusions have been reached in this context in the past several years. Research thus shows, for example, that nursing staff with completed higher levels of education believe that coercive measures can be a therapeutic tool suitable for the specific treatment of aggressive patients, while those with lower levels of education consider them to be an essential means of subduing patients who are restless, disturb the medical personnel or interfere with other patients. Although less educated staff understand that the use of coercive measures incites feelings of humiliation and undue punishment in affected patients, they nonetheless harbour a less negative stance towards coercive measures overall compared to their higher educated colleagues, and are more inclined to use them (Gelkopf, et al., 2009). This has led some researchers to conclude that the practical incidence of coercive measure use is primarily dependant on the training and education of the nursing staff (Morgan, 2011; Moylan \& Cullinan, 2011). Further research has revealed that female nursing staff perceive coercive measures as less therapeutic and more punitive in nature, compared to male nursing staff, and are on average less inclined to administer them (Gelkopf, et al., 2009). Nursing staff who work in closed psychiatric wards and have a more direct experience with aggressive patients are in general inclined to believe that coercive measures may be used as a therapeutic means, but do not view them as a legitimate punitive measure (Gelkopf, et al., 2009; Van der Merwe, et al., 2013). Existing studies thus clearly indicate that the key factors affecting the incidence rates of coercive measure use in psychiatric health care practice are mainly the sex of the nursing staff, their workplace (open/closed ward), and their level of education.

\section{Aims and objectives}

Our research aimed to assess the attitude of Slovene psychiatric nursing professionals towards the use of mechanical restraint. The purpose of this research is to establish whether the attitude of Slovenian nursing staff is affected by the same factors and learn whether certain local special characteristics or deviations can be observed in comparison to the conclusions of the research conducted abroad.

\section{Methods}

A descriptive and exploratory non-experimental method of empirical research was used in all psychiatric hospitals in Slovenia.

\section{Description of the research instrument}

The questionnaire consisted of two segments. The first one was concerned with demographical data. The second one was represented by a survey modelled after the Heyman survey of nurses' attitudes to seclusion (SNASS) (Heyman, 1987; Bowers, et al., 2004; Happell, 
et al., 2012). From the range of coercive measures, which include physical restraint, mechanical restraint (strapping to a bed), seclusion (the seclusion room) and pharmacological restraint, the conducted survey explored the attitude of nursing staff specifically regarding the use of mechanical constraint. The survey consisted of five items: 1) reasons for using mechanical restraints and their justification, 2) sentiments of staff regarding mechanical restraint use, 3) respondents' opinion about the patients' reaction to mechanical restraints and the corresponding impact on the patients' overall mood, 4) respondents' opinion on the effectiveness of mechanical restraints, and 5) changes that the respondents would propose when it comes to mechanical restraint use. Each of the items was addressed separately in the analysis. The survey consisted of three-point and four-point Likert scales. The reliability test - retest of previously executed research ranges between 0.62-0.79 (Happell \& Koehn, 2010). Since the survey was used in Slovenia for the first time, it has been translated to Slovene for the purposes of the research. This was conducted by three independent translators and included a back translation. The survey was then test-completed by 10 nursing employees and found to be clear and consistent. Cronbach Alpha was between 0.64 and 0.80 .

\section{Description of the research sample}

The sample included psychiatric nursing staff from all six psychiatric hospitals in Slovenia. As of 2013, these six hospitals employed 464 psychiatric nursing staff, of which 118 were registered nurses and 346 were health care assistants. The response rate was $79.0 \%$ or 367 respondents of whom $33.9 \%(n=125)$ were male and $66.1 \%(n=242)$ were female. The majority of the respondents, which is $71.8 \%(n=264)$, had secondary school-level nursing education (health care assistant, HCA), while the remainder had a bachelor's degree in nursing (registered nurse, $\mathrm{RN}$ ) or a post-graduate degree. Most $(n=255,69.6 \%)$ respondents had already worked in a closed psychiatric ward.

\section{Description of the research procedure and data analysis}

Participation in the survey was voluntary and the questionnaire was anonymous. Research was conducted in 2013/2014 in all psychiatric hospitals in Slovenia after we had received their consent. Mechanical restraint and seclusion are the only allowed coercion measures in Slovenian psychiatric hospitals (Mental Health Act, 2008), however, mechanical restraint has been the only coercive measure used in Slovenian psychiatric hospitals so far. The terms "mechanical restraint" and "coercive measure" are therefore used interchangeably in the article. In the Introduction "coercive measures" is used since a general review of literature on coercive measures is given. Elsewhere in the article, we used the term "mechanical restraint" because the content of the article is based on Slovenian circumstances.

Analysis was conducted using SPSS ver. 20 (IBM, SPSS Inc., Chicago, IL, USA). The results were considered statistically significant at $p<0.05$. In addition to the basic descriptive statistics, a MannWhitney $U$ test was used to compare statistically significant differences between two samples, and a Kruskal-Wallis test was used to compare statistically significant differences between more than two samples. Within the framework of the correlational method, the Spearman correlation coefficient $\rho$ was used to assess the correlation between two ordinal variables, or between an ordinal and an interval variable. The Pearson $\chi^{2}$ test was used to verify the independence of two variables in the contingency table.

\section{Results}

The decision to use mechanical restraints is most often made by doctors, 273 (75.2\%), followed by health care assistants, 56 (15.4\%) and finally, registered nurses, $33(9.2 \%)$. The majority of respondents, $123(56 \%)$ assessed that the average duration of a mechanical restraint used on a patient is up to 4 hours; $46(13.4 \%)$ respondents assessed that the average duration of a mechanical restraint is up to 6 hours; and $105(30.6 \%)$ assessed that the average duration of a mechanical restraint is more than 8 hours. The results show statistically significant differences in the assessment of mechanical restraint duration between the individual hospitals $\left(\chi^{2(2)}=43.770, p<\right.$ 0.001 ). Males statistically significantly decide to use a mechanical restraint for a longer time duration $(U=$ $11184.50, p=0.012)$. The age of the worker $(\rho=$ $-0.071, p=0.187)$, their education level $(\rho=-0.016$, $p=0.775)$ and work position $(U=11296.50, p=0.193)$ have not been found to be significantly connected to the average length of mechanical restraint use.

When asked to assess the optimal duration of mechanical restraint use, $79(23.5 \%)$ respondents stated that they believed that a mechanical restraint should last more than 4 hours. 119 (35.4 \%) respondents stated that a mechanical restraint should last less than 4 hours. 13 (3.86\%) respondents stated that they did not approve of mechanical restraint use at all. The greatest share of respondents, namely 126 (37.2\%), were unable to choose an appropriate answer. Females statistically significantly more often believe that the duration of a mechanical restraint should be longer $(U=11057.00, p=0.024)$ compared to males. The age of the staff $(\rho=0.022, p=0.694)$, their level of education $(\rho=0.021, p=0.662)$ and work position $(U=$ $11446.50, p=0.737)$ are not significantly connected to the perceived optimal duration of the mechanical 


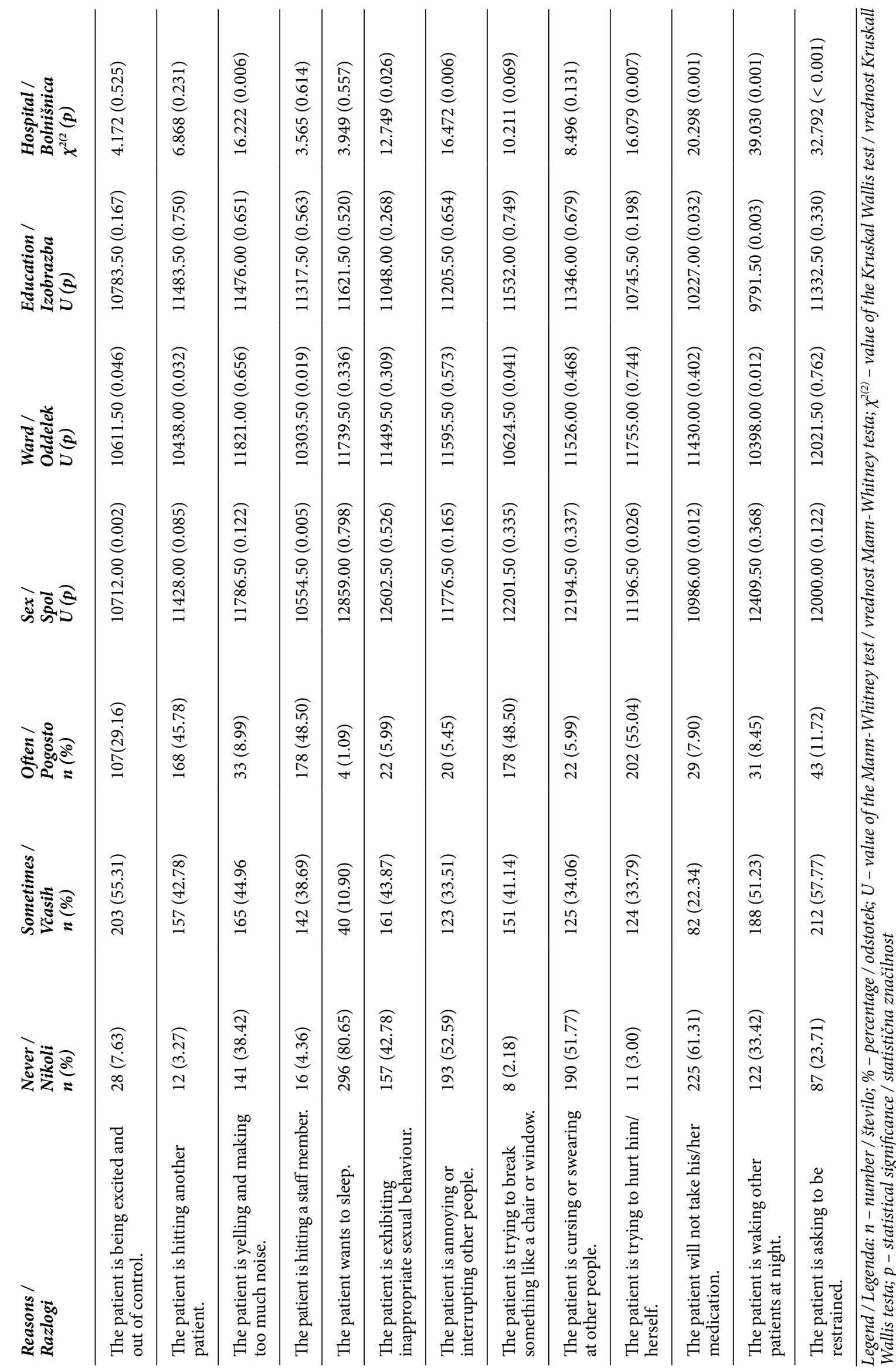


restraint use. The results have shown statistically significant differences in the respondents' perceived optimal duration of mechanical restraint use between the individual hospitals $\left(\chi^{2(2)}=17.525, p=0.004\right)$.

\section{Reasons for the use of mechanical restraints}

Regarding the reasons for mechanical restraint use, respondents most often stated these to be damaging hospital inventory ( $n=329,89.64 \%)$, auto-aggressive behaviour $(n=326,88.6 \%)$, aggressive behaviour towards other patients $(n=325,88.56 \%)$, and aggression towards hospital personnel $(n=320$, $87.19 \%)$. Certain statistically significantly differences appear in this context according to the sex, work position (closed / open ward), level of education and hospitals (Table 1).

\section{Justification for the use of mechanical restraints}

From the behaviours listed in the survey in Table 1 , respondents had to decide for the reason which is most justified for implementing mechanical restraints. They considered auto-aggressive behaviour to be the most highly justified reason for the use of mechanical restraints $326(88.6 \%)$, followed by damaging of hospital inventory $(n=322,87.7 \%)$, aggressive behaviour towards other patients $(n=314,85.5 \%)$, aggression towardshospital personnel $(n=310,84.4 \%)$, and finally, patient being excited and out of control $(n=$ $287,78.2 \%)$.

\section{Mood of patients during the administering of mechanical restraints}

Most respondents believe that patients who are subjected to a mechanical restraint feel angry $(n=328$, $89.4 \%)$, controlled $(n=292,79.6 \%)$, powerless $(n=$ $288,78.5 \%)$, scared $(n=267,72.8 \%)$, helpless $(n=266$, $72.5 \%)$, frightened $(n=231,62.9 \%)$, appalled $(n=$ $213,58 \%)$, confused $(n=210,57.2 \%)$, punished $(n=$ $188,51.2 \%)$, or safe $(n=145,39.5 \%)$. Compared to females, males more often perceive mechanical restraints to be punitive in nature $(U=10829.00 ; p=$ 0.003 ) and consider that they are happy during mechanical restraints $(U=11657.00, p=0.048)$. Staff working in closed wards rate the mood of patients as less satisfied $(U=10511.50, p=0.014)$ and those with lower education qualifications consider patients to be more powerless ( $U=11009.00, p=0.034$ ) when subjected to mechanical restraints compared to staff working in open wards. The individual hospitals results showed statistically significant differences in several areas: that patients feel relieved $\left(\chi^{2(2)}=15.003\right.$, $p=0.010)$, feel safe $\left(\chi^{2(2)}=20.137, p=0.001\right)$, feel disgusted $\left(\chi^{2(2)}=13.512, p=0.019\right)$, feel punished $\left(\chi^{2(2)}=11.200, p=0.048\right)$ and feel out of control $\left(\chi^{2(2)}=\right.$ $12.358, p=0.030)$.

\section{Sentiments of nursing staff following the use of mechanical restraints}

Psychiatric nursing staff are confronted with different sentiments after having administered mechanical restraints (Table 2). Females feel less satisfaction in helping patients $(U=11221.50, p=$ $0.010)$, are less relieved $(U=10699.50, p=0.001)$, are less satisfied with everything running smoothly $(U=9580.00, p<0.001)$, feel less disempowered $(U=11450.50, p<0.025)$, feel less in control of the situation $(U=10234.50, p<0.001)$ and feel less fed up $(U=11722.50, p=0.018)$. According to the type of ward, open-ward nurses feel that they have more control over the situation $(U=9802.00, p=0.003)$. Respondents with a higher level of education feel less satisfaction in helping patients $(U=9527.00, p=$ $0.002)$, feel less powerful ( $U=11300.00, p=0.004)$ and have a sense of being disempowered after having administered a mechanical restraint on a patient $(U=$ 10131.00, $p<0.009$ ). Differences in the respondents' answers according to the hospitals are stated in Table 2.

\section{Effect of mechanical restraints on patients}

Most respondents ( $n=343,91.6 \%)$ believe that mechanical restraints are successful in calming the patients. Compared to males, females statistically significantly more often believe that mechanical restraints are successful in calming the patients $(U=$ 12299.00, $p=0.050$ ), improve their current behaviour $(U=11498.00, p=0.016)$, make patients feel like staff is worried about them $(U=1165.00, p=0.010)$, or do not help the patients in any way $(U=10685.50, p$ $=0.003)$. Those working in closed wards statistically significantly more often believe that mechanical restraints make them frustrated $(U=10712.00, p=$ $0.025)$ and make patients angry at the staff $(U=10.455$, $p=0.011)$. With regard to education levels there are not any significant differences. Regarding different hospitals, please see Table 3 .

\section{Proposed changes to mechanical restraint administration}

Respondents believe certain suggestions would improve the administration of mechanical restraints (Table 4). Females more often than males agree that patients undergoing mechanical restraints should have the possibility of listening to music if they want to $(U=10358.00, p<0.001)$, that the room where mechanical restraints are being administered should be comfortable, unlocked and at the disposal of patients should they want to be restrained themselves $(U=10344.50, p=0.001)$, that mechanical restraints should not be used at all $(U=9257.50, p<0.001)$, that the room where mechanical restraints are administered 


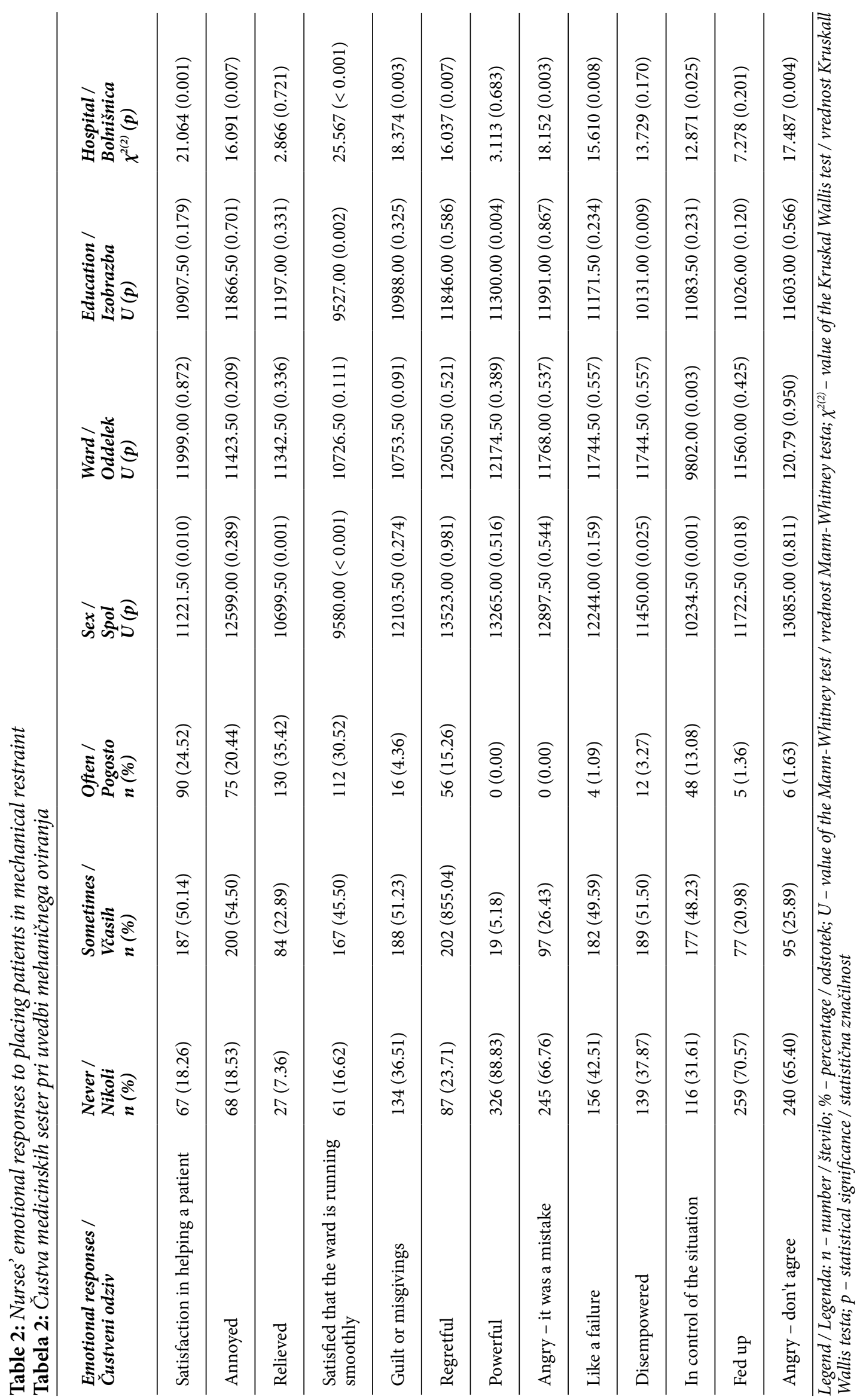




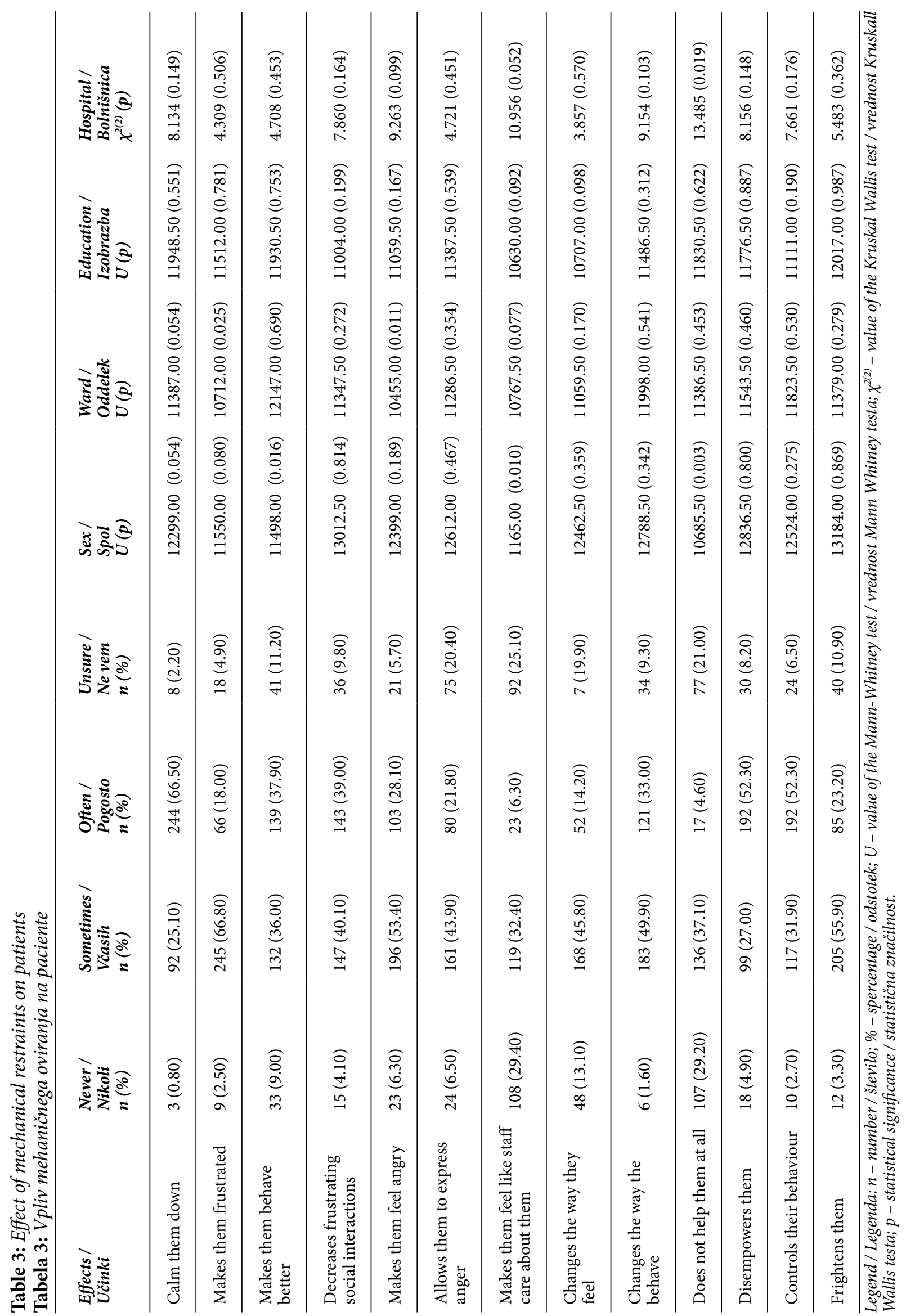




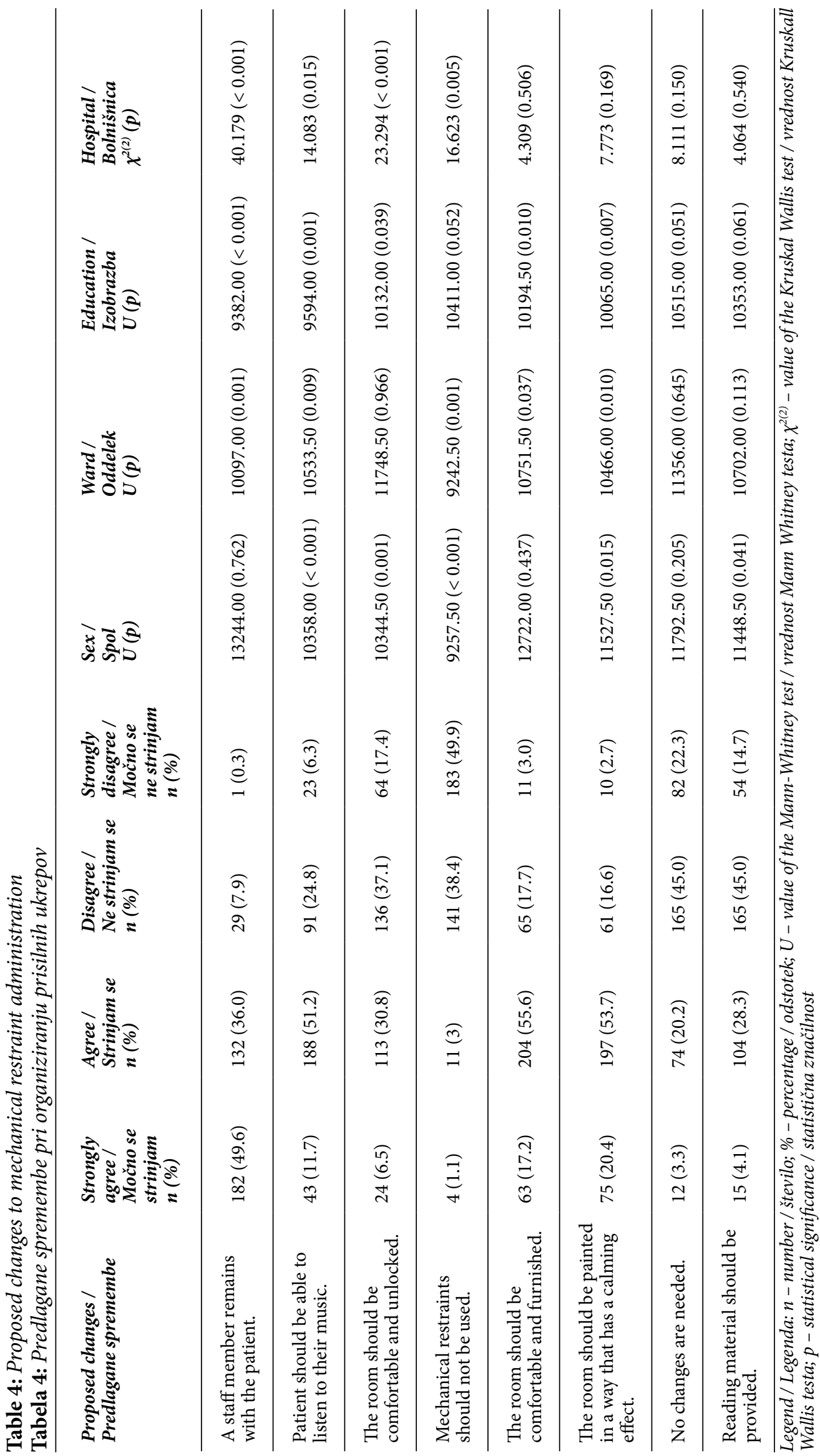


should be painted in relaxing colours $(U=11527.50$, $p=0.015)$, and that patients should have books and magazines for reading at their disposal $(U=11448.50$, $p=0.041)$. Compared to staff with completed secondary-level education, higher educated staff more often agree that a staff member should always remain with a patient who is being restrained $(U=9382.00$, $p<0.001)$, that patients should be allowed to listen to music if they wish to $(U=9594.00, p=0.001)$, that the room where restraint is being administered should be comfortable, unlocked and at the disposal of patients should they want to be restrained themselves $(U=10132.00, p=0.039)$, that the bed where mechanical restraint is being administered should be more comfortable $(U=10194.50, p=0.010)$, and the room painted in relaxing colours $(U=10065.00, p=$ 0.007). Compared to those working in open wards, staff working in closed wards more often agree that a staff member should always remain with a patient who is being restrained $(U=10097.00, p=0.001)$, that patients should be allowed to listen to music if they want to $(U=10533.00, p=0.009)$, that mechanical restraints should not be used at all $(U=9242.50, p<$ $0.001)$, that beds should be more comfortable $(U=$ $10751.50, p=0.037$ ) and that the room where restraint is being administered should be painted in relaxing colours $(U=10466.00, p=0.010)$. According to the different hospitals see Table 4.

\section{Discussion}

Research results reveal certain significant differences in the attitude towards the use of mechanical restraints among the nursing staff in individual psychiatric institutions, and differences depending on the sex, education and work position of the psychiatric nursing staff. In Slovenia, the decision to use mechanical restraints is most often made by doctors. Only in roughly one quarter of cases is the decision to use mechanical restraints made by the nursing staff. In this context, some researchers reached diametrically opposite results in their own research, as in their region, over three quarters of decisions to use mechanical restraints are made by nursing staff instead (Happell \& Koehn, 2010; Happell, et al., 2012). Due to these differences in conditions on the national level, it is difficult to compare the willingness of nursing staff to administer mechanical restraints between these two cases of research. The aforementioned differences can be attributed to the differences in the mental health care legislation of an individual country. Circumstances in Slovenia are the result of the current Slovenian Mental Health Act (2008), which prescribes that every final decision to administer a mechanical restraint must be made by a doctor. Only in cases where that is considered impossible, other health care workers can make this decision independently, and a doctor must then check on the patient's condition as soon as possible and decide on further measures. In this context, the literature suggests that it is possible to ascertain that the field of mechanical restraints in examined regions has been regulated with new the legislation, which fundamentally decreased the incidence of mechanical restraint use and increased the overall safety of treating mentally ill patients. Regardless of the fact that in Slovenia the law puts full responsibility regarding the use of mechanical restraints on doctors, it should be noted that nursing staff are those that propose the use of a mechanical restraint in the first place, or are the ones forced to implement a measure when this is absolutely necessary, before a doctor is able to arrive on site (Bregar \& Možgan, 2012).

The average duration of an administered mechanical restraint differs across countries. Nearly half of Slovene respondents are inclined to believe that a mechanical restraint should be used for more than 4 hours at a time, as opposed to foreign research, where nursing staff was observed to prefer a shorter time. Furthermore, compared to the research (Happell \& Koehn, 2010; Happell, et al., 2012), the ratio of Slovene nursing staff who think mechanical restraints should not be used in clinical practice at all is less than half of that observed in foreign findings. Most indicators thus point at the conclusion that Slovene nursing staff are relatively highly inclined to the use of mechanical restraints at this time.

Another point of note was that, considering Slovenia has a highly restrictive legislation governing the use of mechanical restraints in psychiatry, and strict guidelines concerning their application, justification and duration, the research has surprisingly shown considerable statistically significant deviations in the average duration of an administered mechanical restraint and attitudes of the nursing staff between separate domestic institutions. This leads us to conclude that significant differences exist in the professional approach of specific clinical environments in spite of a uniform legislation. Similar to our own research, foreign research was also mostly focused on microfactors related to the characteristics of the employees, the micro-environment and the attitude of personnel towards administering mechanical restraints (Gelkopf, et al., 2009; Happell \& Koehn, 2010; Muir-Cochrane, et al., 2015). Although these factors have already been researched to a considerable degree, we are yet to see notable changes in clinical practice on the level of a single country, which is also exemplified by our own research on the sizeable differences mentioned above between individual hospitals in Slovenia, which, in theory, should not be occurring given the legislative and expert framework. This is why the results of our research and others (Bregar, et al., 2018) mentioned before lead us to believe other essential factors affecting the incidence of mechanical restraint use in practice must exist and that they have been insufficiently treated and explored 
or were even left out of existing research. Therefore, the management sphere of individual hospitals is one particular factor that should be examined closely. Also, when comparing the incidence of coercive measures between hospitals on an international level, the differences in hospital characteristics (e.g. staffing, ward characteristics etc.) should be carefully taken into consideration.

Auto- and hetero-aggression, and states of high agitation were shown to be the most frequent justification for the use of mechanical restraints, similar to indications of foreign research (Migon, et al., 2008; Gelkopf, et al., 2009). Our respondents, on the other hand, justified the use of mechanical restraints outside the auto or hetero-aggressive behaviour (the patient is becoming excited and out of control, the patient is yelling and making noise, the patient wants to sleep, the patient is annoying or interrupting other people, refuses to take medications, is waking up other patients at night, or asks for a mechanical restraint to be used on him/herself) comparatively more often in relation to foreign studies (Gelkopf, et al., 2009; Happell \& Koehn, 2010). This again leads us to believe that mechanical restraints are administered relatively often to Slovene patients as respondents also more often assessed a range of non-aggressive behaviours as proper justification for using mechanical restraints on patients compared to Happell and colleagues (2012).

Compared to foreign research (Gelkopf, et al., 2009; Roberts, et al., 2009; Happell \& Koehn, 2010; Happell, et al., 2012; Van der Merwe, 2013), Slovene respondents less frequently perceive patients' emotions to be negative during the administering of mechanical restraints, as well as stating that they believe their patients to be more satisfied and less threatened by the use of mechanical restraints on average. Staff describe experiencing various kinds of sentiments after having administered a mechanical restraint. Domestic respondents less often report regretting the use of a mechanical restraint and in general appear to be more inclined to use these measures compared to the conclusions of foreign research (Happell \& Koehn, 2010). Respondents in general believe that mechanical restraints have a calming effect on the patients, that they allow patients to release their anger in a safer and more controlled manner, and that these measures make patients reconsider and change their behaviour. All in all, it can be concluded that psychiatric nursing staff in general make erroneous assumptions that the administration of mechanical restraints can have a certain therapeutic effect (Gelkopf, et al., 2009; Happell \& Koehn, 2010; Van Der Merwe, et al., 2013). In spite of the generally favourable opinion of Slovene nursing staff with regard to the use of mechanical restraints, our respondents statistically significantly more often stated that certain changes were necessary in the clinical practice of mechanical restraint administration compared to the other study (Happell \& Koehn, 2010).
The cross-comparison of results of survey assertions with factors such as sex, education level and work position (open/closed ward), points to some characteristics that were already established by other researchers (Gelkopf, et al., 2009; Happell \& Koehn, 2010). Male respondents in our research use mechanical restraints more often than females when patients are excited, aggressive, or refuse to take their medication. Males are also more likely to believe that inappropriate sexual behaviour justifies the use of mechanical restraints. Females might be more lenient towards the early signs of aggression and other unwanted behaviour, have a tendency to respond in softer ways, or decide to ask male nursing staff to intervene when improper behaviour begins to escalate. Females more often perceive patients who feel humiliated or unduly punished when they are subjected to mechanical restraints. Our male respondents statistically significantly more often expressed feelings of satisfaction, relief, power, but also regret when it comes to administering a mechanical restraint.

Compared to more educated nursing staff, nursing staff with a completed secondary school more often resort to using mechanical restraints when patients refuse to take their medication or when they wake up other patients at night. These conclusions are in line with several cases of foreign research (Gelkopf, et al., 2009; Happel \& Koehn, 2010; McCabe, et al., 2011; Fariña-López, et al., 2014). A possible explanation for the staff's attitude towards mechanical restraints can be that the staff had not been suitably educated or is the result of the fact that staff who are lower educated more often work in night shifts, when fewer staff are present in the ward in general to assist in controlling situations. Since staff are spread thin during the night, they are likely to see restraint as the safest and easiest solution to any issues affecting patient behaviour. Highly educated staff less often believe that inappropriate sexual behaviour, waking up other patients at night, and the necessity to go to sleep are good reasons to administer mechanical restraints. It is possible that less educated staff decide to restrain the patient in aforementioned cases due to the lack of capacity or time to deal with the patient in other ways, or due to a specific attitude towards mechanical restraints in general. Compared to their more educated colleagues, staff with lower education more often experience satisfaction and feelings of power and control when administering mechanical restraints, while more highly educated staff often experience feelings of disempowerment. In this context, we should note that staff with lower education qualifications most often carry out instructions and have a smaller degree of responsibility. Perhaps those rare opportunities where they are the ones making the decision to use mechanical restraints bring them feelings of control and satisfaction that they might not experience when performing tasks ordered by superior 
staff. Across the board, positive sensations (satisfaction, relief, power) and a more favourable attitude towards using mechanical restraints appear statistically significantly more often in lower educated staff, which corroborates the findings of foreign research in this context as well (Gelkopf, et al., 2009).

Nursing staff respondents (those who are higher educated, females and those working in closed wards) in our research expressed a desire for changes to be made to the implementation of mechanical restraints, which indicates that they are concerned about the well-being of their patients. It should be emphasised that although our research corroborates the relevance of certain factors of psychiatric nursing staff's attitude in this area, as concerns their mentality regarding mechanical restraint use and its correlation with the practical incidence of the use, our results also clearly show that not enough focus has been placed on the broader context of the hospital environment, especially the management of individual hospitals, which we assert to be the key factor for more effective changes in the future.

The research was based on a non-random, accessible sample, and respondents were not selected according to a balanced ratio of sexes, education levels or work positions. The Heyman-type survey that was used cannot provide a simple assessment of the general attitude of nursing staff towards the use mechanical restraints. Quite a few respondents did not answer all the questions of the survey. Since excluding such respondents would considerably decrease the number of respondents, we decided not to exclude them. This is also the reason why the number of respondents varies throughout the survey.

\section{Conclusion}

Our research concludes that psychiatric nursing staff in Slovene hospitals is, overall, relatively more inclined towards using mechanical restraints compared to most instances of foreign research. Furthermore, male staff, nursing staff with a lower level of education and those working in open wards are more inclined to use mechanical restraints compared to their counterparts. Our key finding is that considerable differences appear in the average duration of an administered mechanical restraint and attitudes of nurses towards the mechanical restraints between individual Slovene psychiatric hospitals. This leads us to believe that patients are subjected to different practices of mechanical restraint use in individual establishments, although Slovene legislation is unified and prescriptive. An essential factor affecting mechanical restraint use in practice thus appears to be the policy, guidelines and attitude of the hospital's management, a subject that warrants further investigation domestically as well as abroad. Future research in this context should focus on the most appropriate legal framework and the study of hospital management policy in relation to coercive measures used internally, as these both seem to affect incidence rates to a considerable degree.

\section{Acknowledgements / Zahvala}

The authors would like to acknowledge the support of nursing directors, Professional Group of Nurses and Health Technicians in Psychiatry and all respondents in psychiatric hospitals in Slovenia who participated in the research. / Avtorji se želijo zahvaliti pomočnikom direktorjev za zdravstveno nego, Sekciji medicinskih sester in zdravstvenih tehnikov $\mathrm{v}$ psihiatriji ter vsem sodelujočim v psihiatričnih bolnišnicah v Sloveniji, ki so sodelovali v raziskavi.

\section{Conflict of interest / Nasprotje interesov}

The authors declare that no conflicts of interest exist. / Avtorji izjavljajo, da ni nasprotja interesov.

\section{Funding / Financiranje}

The study received no funding. / Raziskava ni bila finančno podprta.

\section{Ethical approval / Etika raziskovanja}

The study was conducted in accordance with the Helsinki-Tokyo Declaration (World Medical Association, 2013) and the Code of Ethics for Nurses and Nurse Assistants of Slovenia (2014). The research received consent from the Republic of Slovenia National Medical Ethics Committee, decision nr. 37/0315. / Raziskava je pripravljena v skladu z načeli Helsinško-Tokijske deklaracije (World Medical Association, 2013) in v skladu s Kodeksom etike v zdravstveni negi in oskrbi Slovenije (2014). Raziskava je dobila soglasje Komisije Republike Slovenije za medicinsko etiko, odločba št. 37/0315.

\section{Author contributions / Prispevek avtorjev}

Branko Bregar conceptualized and designed the study, conducted the study, statistical analysis and interpretation of the results. Brigita Skela Savič conceptualized and designed the study, interpreted the data, and she is the author's secondsupervisorand consultant. Karmen Kajdiž participated in statistical analysis and interpretation of the results. Blanka Kores Plesničar conceptualized and designed the study, revised the manuscript, and she is the author's first supervisor and consultant. All co-authors contributed to the writing process, and had full access to the data, read, and approved the final manuscript. / Branko Bregar je zasnoval in oblikoval raziskavo, izvedel raziskavo, statistično analizo in interpretacijo rezultatov. Brigita Skela Savič je zasnovala in oblikovala raziskavo, interpretirala podatke in je avtorjeva somentorica in 
svetovalka. Karmen Kajdiž je sodelovala pri statistični analizi in interpretaciji rezultatov. Blanka Kores Plesničar je zasnovala in oblikovala raziskavo, pregledala rokopis in je glavna mentorica in svetovalka. Vsi soavtorji so prispevali k procesu pisanja, imeli so popoln dostop do podatkov, prebrali in odobrili so končni rokopis.

\section{Literature}

Bergk, J., Flammer, E. \& Steinert, T., 2010. "Coercion Experience Scale" (CES): validation of a questionnaire on coercive measures. BMC Psychiatry, 10, p. 5.

https://doi.org/10.1186/1471-244X-10-5

Bergk, J., Einsiedler, B., Flammer, E. \& Steinert, T., 2011. A randomized controlled comparison of seclusion and mechanical restraint in inpatient settings. Psychiatric services, 62(11), pp. 1310-1317.

https://doi.org/10.1176/appi.ps.62.11.1310

PMid:22211210

Berzlanovich, A.M., Schöpfer, J. \& Keil, W., 2012. Deaths due to physical restraint. Deutsches Ärzteblatt International, 109(3), pp. 27-32.

https://doi.org/10.3238/arztebl.2012.0027

Bowers, L., Alexander, J., Simpson, A., Ryan, C. \& CarrWalker, P., 2004. Cultures of psychiatry and the professional socialization process: the case of containment methods for disturbed patients. Nurse Education Today, 24(6), pp. 435-442. https://doi.org/10.1016/j.nedt.2004.04.008

PMid:15312952

Bregar, B. \& Možgan, B., 2012. Provision patient's safety in psychiatry - nursing view. In: B. Skela-Savič, S. Hvalič Touzery, K. Skinder Savić, J. Joca, I. Avberšek-Lužnik, et al., eds. 5th International Scientific Conference Quality Health Care Treatment in the Framework of Education, Research and Multiprofessional Collaboration - Towards the Health of Individuals and the Society, 7th - 8th June 2012, Ljubljana, Slovenia. Jesenice: College of Nursing, pp. 444-450.

Bregar, B., Skela-Savič, B. \& Kores Plesničar, B., 2018. Crosssectional study on nurses' attitudes regarding coercive measures: the importance of socio-demographic characteristics, job satisfaction, and strategies for coping with stress. BMC psychiatry, 18(1), p. 171.

https://doi.org/10.1186/s12888-018-1756-1

PMid: 29866142; PMCid: PMC5987471

Declaration of Helsinki - Ethical Principles for Medical Research Involving Human Subjects, 2013. Fortaleza: The World Medical Association.

Ejneborn Looi, G.M., Engström, Å. \& Sävenstedt, S., 2015. A self-destructive care: self-reports of people who experienced coercive measures and their suggestions for alternatives. Issues in Mental Health Nursing, 36(2), pp. 96-103.

https://doi.org/10.3109/01612840.2014.951134
Espinosa, L., Harris, B., Frank, J., Armstrong-Muth, J., Brous, E., Moran, J., et al., 2015. Milieu improvement in psychiatry using evidence-based practices: the long and winding road of culture change. Archives of Psychiatric Nursing, 29(4), pp. 202-207.

https://doi.org/10.1016/j.apnu.2014.08.004

Fariña-López, E., Estévez-Guerra, G.J., Gandoy-Crego, M., Polo-Luque, L.M., Gómez-Cantorna, C. \& Capezuti, E.A., 2014. Perception of Spanish nursing staff on the use of physical restraints. Journal of Nursing Scholarship, 46(5), pp. 322-330. https://doi.org/10.1111/jnu.12087

Gates, D.M., Gillespie, G.L. \& Succop, P., 2011. Violence against nurses and its impact on stress and productivity. Nursing Economics, 29(2), pp. 59-66.

PMid:21667672

Gelkopf, M., Roffe, Z., Behrbalk, P., Melamed, Y., Werbloff, N. \& Bleich, A., 2009. Attitudes, opinions, behaviours, and emotions of the nursing staff toward patient restraint. Issues in Mental Health Nursing, 30(12), pp. 758-763.

https://doi.org/10.3109/01612840903159777

Happell, B., Dares, G., Russell, A., Cokell, S., Platania-Phung, C. \& Gaskin, C. J., 2012. The relationships between attitudes toward seclusion and levels of burnout, staff satisfaction, and therapeutic optimism in a district health service. Issues in Mental Health Nursing, 33(5), pp. 329-336.

https://doi.org/10.3109/01612840.2011.644028

PMid:22545640

Happell, B. \& Koehn, S., 2010. Attitudes to the use of seclusion: has contemporary mental health policy made a difference. Journal of Clinical Nursing, 19(21/22), pp. 3208-3217. https://doi.org/10.1111/j.1365-2702.2010.03286.x

Heyman, E., 1987. Seclusion. Journal of Psychosocial Nursing and Mental Health Services, 25(11), pp. 9-12.

PMid:3694565

Hollins, L. \& Stubbs, B., 2011. Managing the risk associated with physical intervention: a discussion paper. The British Journal of Forensic Practice, 13(4), pp. 257-263.

https://doi.org/10.1108/14636641111190015

Janssen, W.A., van de Sande, R., Noorthoorn, E.O., Nijman, H.L., Bowers, L., Mulder, C.L., et al., 2011. Methodological issues in monitoring the use of coercive measures. International Journal of Law and Psychiatry, 34(6), pp. 429-438.

https://doi.org/10.1016/j.ijlp.2011.10.008

Knutzen, M., Bjørkly, S., Eidhammer, G., Lorentzen, S., Helen Mjøsund, N., Opjordsmoen, S., et al., 2013. Mechanical and pharmacological restraints in acute psychiatric wards: why and how are they used. Psychiatry Research, 209(1), pp. 91-97. https://doi.org/10.1016/j.psychres.2012.11.017 
Kodeks etike $v$ zdravstveni negi in oskrbi Slovenije, 2014. Ljubljana: Zbornica zdravstvene in babiške nege Slovenije - Zveza strokovnih društev medicinskih sester, babic in zdravstvenih tehnikov Slovenije.

McCabe, D.E., Alvarez, C.D., McNuty, S.R. \& Fitzpatrick, J.J., 2011. Perceptions of physical restraints use in the elderly among registered nurses and nurse assistants in a single acute care hospital. Geriatric Nursing, 32(1), pp. 39-45.

https://doi.org/10.1016/j.gerinurse.2010.10.010

PMid:21146901

Mental Health Act. Official Gazette of the RS nr. 77/2008.

Migon, M.N., Coutinho, E.S., Huf, G., Adams, C.E., Cunha, G.M. \& Allen, M.H., 2008. Factors associated with the use of physical restraints for agitated patients in psychiatric emergency rooms. General Hospital Psychiatry, 30(3), pp. 263-268. https://doi.org/10.1016/j.genhosppsych.2007.12.005

Morgan, S., 2011. Ethical issues in patient restraint. Nursing Times, 107(9), pp. 22-25.

Moylan, L.B. \& Cullinan, M., 2011. Frequency of assault and severity of injury of psychiatric nurses in relation to the nurses' decision to restrain. Journal of Psychiatric and Mental Health Nursing, 18(6), pp. 526-534.

https://doi.org/10.1111/j.1365-2850.2011.01699.x

Muir-Cochrane, E.C., Baird, J. \& McCann, T.V., 2015. Nurses' experiences of restraint and seclusion use in short-stay acute old age psychiatry inpatient units: a qualitative study. Journal of Psychiatric and Mental Health Nursing, 22(2), pp. 109-115. https://doi.org/10.1111/jpm.12189

Raboch, J., Kalisová, L., Nawka, A., Kitzlerová, E., Onchev, G., Karastergiou, A., et al., 2010. Use of coercive measures during involuntary hospitalization: findings from ten European countries. Psychiatric Services, 61(10), pp. 1012-1017.

https://doi.org/10.1176/appi.ps.61.10.1012

Roberts D., Crompton D., Milligan, E. \& Groves, A., 2009. Reflections on the use of seclusion in an acute mental health facility. Journal of Psychosocial Nursing and Mental Health Services, 47(10), pp. 25-31.

https://doi.org/10.3928/02793695-20090902-01

PMid:19835317
Soininen, P., Putkonen, H., Joffe, G., Korkeila, J. \& Välimäki, M., 2014. Methodological and ethical challenges in studying patients' perceptions of coercion: a systematic mixed studies review. BMC Psychiatry, 14, p. 162.

https://doi.org/10.1186/1471-244X-14-162

PMid:24894162; PMCid:PMC4051960

Steinert, T., Birk, M., Flammer, E. \& Bergk, J., 2013. Subjective distress after seclusion or mechanical restraint: one-year followup of a randomized controlled study. Psychiatric Services, 64(10), pp. 1012-1017.

https://doi.org/10.1176/appi.ps.201200315

PMid:23771400

Stewart, D., Van der Merwe, M., Bowers, L., Simpson, A. \& Jones, J., 2010. A review of interventions to reduce mechanical restraint and seclusion among adult psychiatric inpatients. Issues in Mental Health Nursing, 31(6), pp. 413-424.

https://doi.org/10.3109/01612840903484113 PMid:20450344

Strout, D.T., 2010. Perspectives on the experience of being physically restrained: an integrative review of the qualitative literature. International Journal of Mental Health Nursing, 19(6), pp. 416-427.

https://doi.org/10.1111/j.1447-0349.2010.00694.x

PMid:21054728

Van der Merwe, M., Muir-Cochrane, E., Jones, J., Tziggili, M. \& Bowers, L., 2013. Improving seclusion practice: implications of a review of staff and patient views. Journal of Psychiatric and Mental Health Nursing, 20(3), pp. 203-215.

https://doi.org/10.1111/j.1365-2850.2012.01903.x

PMid:22805615

Whitecross, F., Seeary, A. \& Lee, S., 2013. Measuring the impacts of seclusion on psychiatry inpatients and the effectiveness of a pilot single-session post-seclusion counselling intervention. International Journal of Mental Health Nursing, 22(6), pp. 512-521.

https://doi.org/10.1111/inm.12023

PMid:23682907

World Medical Association, 2013. World Medical Association Declaration of Helsinki: ethical principles for medical research involving human subjects. Journal of the American Medical Association, 310(20), pp. 2191-2194.

https://doi.org/10.1001/jama.2013.281053

Cite as / Citirajte kot:

Bregar, B., Skela-Savič, B., Kajdiž, K. \& Kores Plesničar, B., 2018. The Heyman Survey of nursing employees' attitudes towards mechanical restraints in Slovenia. Obzornik zdravstvene nege, 53(1), pp. 18-30.

https://doi.org/10.14528/snr.2019.53.1.275 